Review

\title{
Carbon Lock-Out: Advancing Renewable Energy Policy in Europe
}

\author{
Paul Lehmann ${ }^{1, *}$, Felix Creutzig ${ }^{2}$, Melf-Hinrich Ehlers ${ }^{3}$, Nele Friedrichsen ${ }^{4}$, \\ Clemens Heuson ${ }^{1}$, Lion Hirth ${ }^{5}$ and Robert Pietzcker ${ }^{6}$
}

1 Helmholtz Centre for Environmental Research, UFZ, Department of Economics, Permoserstr. 15, 04315 Leipzig, Germany; E-Mail: clemens.heuson@ufz.de

2 Technical University Berlin, Department of Economics of Climate Change, Straße des 17. Juni 145, 10623 Berlin, Germany; E-Mail: creutzig@mailbox.tu-berlin.de

3 University of York, Environment Department, Heslington, York, YO10 5DD, UK;

E-Mail: melf.ehlers@york.ac.uk

4 Bremer Energie Institut, Jacobs University Bremen, College Ring 2, Res V, 28759 Bremen, Germany; E-Mail: friedrichsen@bremer-energie-institut.de

5 Consultant, Solmstr. 24, 10961 Berlin, Germany; E-Mail: lion.hirth@googlemail.com

6 Potsdam Institute for Climate Research, PIK, Telegraphenberg A 31, 14473 Potsdam, Germany;

E-Mail: pietzcker@pik-potsdam.de

* Author to whom correspondence should be addressed; E-Mail: paul.lehmann@ufz.de;

Tel.: +49-341-235-1076; Fax: +49-341-235-1836.

Received: 1 November 2011; in revised form: 16 January 2012 / Accepted: 8 February 2012 /

Published: 15 February 2012

\begin{abstract}
As part of its climate strategy, the EU aims at increasing the share of electricity from renewable energy sources (RES-E) in overall electricity generation. Attaining this target poses a considerable challenge as the electricity sector is "locked" into a carbon-intensive system, which hampers the adoption of RES-E technologies. Electricity generation, transmission and distribution grids as well as storage and demand response are subject to important path dependences, which put existing, non-renewable energy sources at an advantage. This paper examines how an EU framework for RES-E support policies should be designed to facilitate a carbon lock-out. For this purpose, we specify the major technological, economic and institutional barriers to RES-E. For each of the barriers, a policy review is carried out which assesses the performance of existing policy instruments and identifies needs for reform. The review reveals several shortcomings: while policies targeting generation are widely in place, measures to address barriers associated with
\end{abstract}


electricity grids, storage and demand are still in their infancy and have to be extended. Moreover, the implementation of policies has been fragmented across EU Member States. In this respect, national policies should be embedded into an integrated EU-wide planning of the RES-E system with overarching energy scenarios and partially harmonized policy rules.

Keywords: carbon lock-in; demand management; electricity; energy policy; feed-in tariff; electricity generation; grids; renewable energy sources; storage

\section{Introduction}

Using renewable energy sources is a major option of climate change mitigation [1]. It also forms an important pillar of the EU's climate strategy. By 2020, at least $20 \%$ of the EU's final energy consumption shall be provided by renewable energy sources [2]. This implies that electricity from renewable energy sources (RES-E) has to provide at least $37 \%$ of overall electricity generation [3], up from 13\% in 1990 and 18\% in 2008 [4]. Figure 1 illustrates that RES-E generation has grown in most EU countries in the last two decades. But the growth rates diverge across EU countries, and the ambitious 2020 targets are in jeopardy. Albeit virtually all EU Member States have implemented RES-E support policies [5], important barriers have limited their success up to now. The electricity sector is "locked" into a carbon-intensive system: A variety of technological, economic and institutional patterns of the system favour the use of fossil energy sources and hamper the adoption of RES-E technologies [6]. These considerations raise several questions: Have existing RES-E policies been designed properly to promote a carbon lock-out? Do they address all relevant barriers to RES-E adoption? Are RES-E policies sufficiently coordinated among another? A re-evaluation is also required as RES-E support schemes have recently been bashed for being ineffective and inefficient instruments of climate policy, suggesting that the EU Emissions Trading Scheme (EU ETS) alone provides for an efficient attainment of climate targets and will induce sufficient levels of RES-E adoption [7-9].

This paper specifies the characteristics of the carbon lock-in and highlights major barriers to RES-E adoption related to electricity generation, transmission, distribution, and storage and demand response. These obstacles cannot be overcome by the EU ETS alone and require a well-defined set of additional policies. To specify this portfolio, a policy review is carried for each of the barriers. The review assesses the effectiveness and efficiency of existing policies to address the different barriers and identifies needs for policy reforms. The analysis reveals that existing policies primarily target barriers associated with RES-E generation, even though these measures can still be improved. In turn, barriers related to electricity transmission and distribution and storage and demand management have been largely neglected. Here the policy portfolio has to be extended significantly. What is more, the implementation of policy measures has been quite fragmented across Member States. National policies have to be embedded into an integrated EU-wide planning of the RES-E system with overarching energy scenarios and partially harmonised policy rules. 
Figure 1. Share of gross electricity consumption generated from renewable energy sources [4].

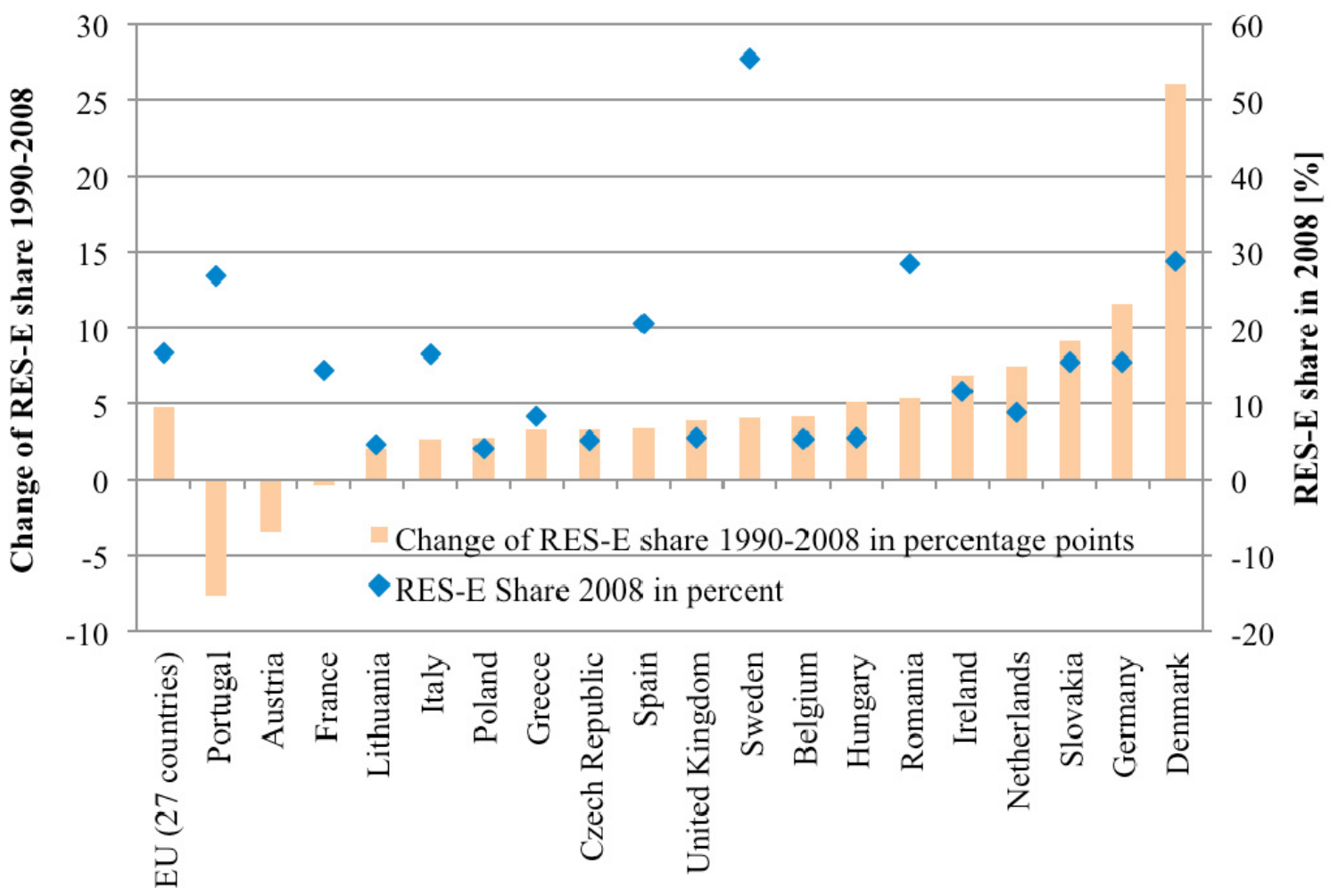

The paper is organized as follows: Section 2 specifies the basic characteristics of path dependency and carbon lock-in in the electricity sector. Subsequently, Sections 3 to 5 outline the barriers associated with electricity generation, grids and storage and demand response, which contribute to the carbon lock-in, and review the corresponding policies. Section 6 addresses overarching integration requirements. Section 7 summarizes the major needs for policy reform and discusses how the corresponding transition process can be spurred.

\section{Path Dependence and Carbon Lock-In in the Electricity Sector}

With more than a century of experience and build-up infrastructure, fossil fuels display numerous advantages for business on business-relevant time scales compared to RES-E technologies. This path dependence produces a carbon lock-in [6]. A path dependence is the result of contingence and increasing returns to scales favouring a certain technology or country without being intrinsically superior to alternatives. Path dependence is by itself neither good nor bad. A carbon lock-in is the result of a specific path dependence favouring fossil-fuel technologies over low-carbon alternatives. Increasing returns to scale by infrastructure provision (e.g., gas pipelines) and agglomeration economics (clustering around the cheapest source of fuel, e.g., in the Ruhr area) are factors fostering path dependence [10]. Sunk investments, or more generally, long-liveability of capital stock create further inertia in the energy system [10,11]. The key reason for a carbon lock-in is non-responsiveness of markets with respect to inter-temporal externalities: Imperfect foresight, uncertainty on future fuel prices and on post-2020 climate targets and policies produce systematic underinvestment in research and development (R\&D) of effective abatement technologies. This is a catch-22: Without these new 
technologies, stricter emission reduction targets may be considered impossible to meet by government, industry and the general public [12]. A carbon lock-in needs to be overcome by a carbon lock-out if the social costs of fossil fuels are assumed to outweigh its advantages. Crucially, the inter-temporal character of the carbon lock-in requires inter-temporal policies, addressing the specific lock-in dimensions. A stationary price instrument, such as the EU ETS, is insufficient [13-15].

Barriers associated with renewable energy generation, grids and storage and demand responses constitute specific carbon lock-ins. Rather than ranking barriers and their policy responses, we suggest addressing them simultaneously. The following sections will discuss these specific barriers, and review appropriate policy responses.

\section{Generation}

\subsection{Learning and Knowledge Spillovers}

\subsubsection{Definition of Barriers}

Crucial factors contributing to a carbon lock-in are learning effects and corresponding knowledge spillovers [13]. The combination of technological learning curves and knowledge in the production of a homogeneous good (electricity) is in fact sufficient to produce path dependence. Technological learning (e.g., worker experience, standardisation and specialisation) provides for unit production costs to shrink with increased cumulative output [16]. Established technologies profit from this learning curve effect and economies of scale and can deter competitors from the market entry [17].

Over the last decade, learning effects have led to significant cost decreases of RES-E technologies such as wind, photovoltaics or concentrated solar power [18-20]. One may presume that they will be able to compete with fossil fuel technologies at some point in future. It is questionable, though, whether this point will be reached in due time. This is primarily due to adverse effects of knowledge spillovers. The knowledge gain of a specific firm emerging from learning-by-doing or R\&D activities is usually also available to rival firms to a certain extent, for instance, due to a lack of nondisclosure or patenting, fluctuation of employees or cooperation between firms [16,21]. Consequently, innovating and learning firms cannot reap the entire social profits of their knowledge. From a macro-economic point of view, a single firm therefore invests too little in learning and $R \& D$, because it only accounts for its own profits, but not for those of its competitors. This also implies that investments in fossil-fuel technologies are excessive, which is particularly detrimental in terms of efficiency as many of these investments are irreversible and sunk [13].

\subsubsection{Policy Review}

The major policy instrument to address learning and knowledge spillovers are schemes to subsidize RES-E generation $[13,22,23]$. In the EU, feed-in tariffs (FITs) have always been competing with (tradable) RES-E quota systems. Many analysts agree that FIT systems have been on average more effective than quota systems in spurring the deployment of RES-E technologies and driving down their learning curve [5,24-34]). For example, after 20 years of FIT support in Germany, average local prices for PV installations have dropped to $\sim 2.5 €(2010) / \mathrm{Wp}$ at the end of 2010 , compared to about 
$\sim 10.4 €(2010) / \mathrm{Wp}$ in 1995 (calculated from PVPS "National Reports" using 2010 exchange rates and German CPI to correct the 1995 value) [35]. A primary reason is that FITs can be easily differentiated by RES-E technologies and date of construction. Thereby, they appropriately account for technology-related differences in learning curves and spillover effects and allow targeted support for innovative but not-yet-competitive technologies [31,32,36]. In contrast, quotas promote primarily those technologies which are closest to the market, and can bring about large rents for these technologies $[32,37,38]$. In the Swedish tradable certificate scheme, observed rents amounted to as much as $55-75 \%$ of the overall remuneration paid to electricity producers [39]. The non-differentiation between construction dates under quota systems also leads to a "dynamic disincentive to invest" in learning technologies: If a technology benefits from learning-by-doing and suffers from spillovers, there is a strong incentive to postpone an investment $[25,37,40]$. This is the case with policies that count every kWh of RES-E against the same quota, so electricity from older, more expensive plants gets the same remuneration as electricity from new, cheaper plants.

A challenge associated with FITs is the uncertainty about actual deployment levels. Information constraints usually lead to remuneration levels that do not exactly reflect true RES-E generation costs and hamper the prediction of future RES-E capacity developments. On the one hand, FITs may be excessive, create large rents for RES-E projects and lead to high policy costs. The corresponding boom in RES-E investments may lead to a strong pressure to abolish the remuneration system. On the other hand, FITs may also turn out to be too low to attain deployment targets. Such problems are unlikely to occur under a quota system where the overall amount of RES-E is fixed. At least in theory, market trades of quotas provide for remuneration levels to adapt continuously and to approximate true RES-E costs over time. However, this calls for a strict enforcement of the quota, which has not always been the case, for example, in the United Kingdom [31].

To control the effectiveness and efficiency of FIT systems, it is crucial to install a feedback mechanism which automatically and promptly adjusts the remuneration to changes in real technology costs [32,41,42]. First FIT feedback mechanisms are currently implemented in Germany, Spain, California and Oregon $[42,43]$. However, an early announced policy revision can lead to a "last-minute panic": many investors may try to finish a project before the FIT is reduced. This drives up prices and increases total FIT cost. Last-minute panic strongly contributed to the 2008 boom in Spain [44] and the 2010 boom in Germany. Consequently, a refined mechanism for responsive degression in the form of a "breathing cap" is needed: As a starting point, national deployment scenarios are developed for every single RES-E technology (see Section 6.1.). The roadmaps should cover a sufficiently long time horizon (at least 3-5 years) to guarantee planning security in terms of investments. Policy makers define technology-specific FITs according to current technology costs and create a degression scheme that reduces the FIT level by a certain percentage each month. Once a RES-E plant is built, its electricity is remunerated for 15-20 years with the fixed tariff that was valid at time of completion. All RES-E installations receiving a FIT have to be reported to a national coordination agency upon completion, thus enabling the comparison of the installed and planned capacity. In case of overinvestment, the FITs for all projects completed afterwards are decreased according to a transparent, fixed formula, e.g., $-2 \%$ remuneration per $5 \%$ overcapacity. In case of underinvestment, a more careful approach is required to reduce the possibility of strategic behaviour of RES-E operators. A brief analysis has to clarify why costs did not decrease as expected, whether the causes are 
permanent or temporary and whether they are related to remuneration or some other reason like bureaucratic procedures and thus could be tackled without increasing the FIT. This feedback process should occur at regular intervals which are chosen proportionally to the realisation time of the respective technology — starting from a time span of one month for photovoltaics and wind.

Such a breathing cap gives rise to several advantages compared to most currently implemented FIT schemes [42,43]: It enables the policy maker to influence both current and medium-term RES-E deployment to a high degree. The feedback mechanism also ensures that the breathing cap closely follows the respective technology's learning curve, i.e., in case of learning effects the mechanism will prevent major rent extractions. Thus, a least-cost achievement of the deployment roadmaps is approached. Through restricting overcapacity due to its short feedback cycle, the breathing cap moreover diminishes the "last-minute panic" to finish a project right before the adjustment date and avoids corresponding strong price increases before that date. The detailed capacity planning together with projected monthly remuneration decrease creates a credible government commitment to a stable long-term RES-E deployment and allows project developers to plan ahead. Using a transparent formula for adjusting the remuneration may further reduce policy risk for RES-E developers. Finally, the breathing cap establishes a common perception of future RES-E deployment on which all investment decisions in the electricity sector and its supply chain can be based, and thus mitigates the costly boom-bust cycles previously observed.

\subsection{Capital Market Restrictions}

\subsubsection{Definition of Barriers}

Risk premiums required on capital markets for renewable energy projects are usually higher than those for fossil-fuel technologies due to higher uncertainties associated with relatively immature RES-E technologies and exogenous risks such as wind speed or sunshine duration [45]. Less experience on the lender side with RES-E technologies will also result in higher risk premiums. The lack of experience includes technological, operational, and regulatory questions. The relative importance of the risk premium is higher than for fossil-fuel technologies since most RES-E technologies are more capital-intensive than conventional generation [46,47].

In addition, the specific characteristics of RES-E investors can lead to major capital market barriers. They are often new and small market entrants, which cannot rely on long-lived relationships with banks, as do large-scale fossil-fuel companies. They can provide less security for loans, and transaction costs of raising capital and hedging risks may be prohibitively high for them [48]. In contrast, large companies have access to a different set of refinance instruments, such as issuing bonds or shares.

\subsubsection{Policy Review}

Overcoming capital market barriers is another important rationale for RES-E support schemes. In this respect, FITs are again superior to quota systems. FITs provide secure income streams for a certain period of time (usually 15-20 years). This implies high investment security for RES-E developers. Correspondingly, the risk premiums and security deposits required by banks are small $[49,50]$. In contrast, capital costs have been significantly higher under quotas, where future remuneration levels 
are variable and market-dependent [25,27,37,38,40,51,52]. In this respect, FITs are more suitable to overcome capital-market barriers and reduce RES-E deployment costs.

\subsection{Uneven Political Playing Field}

\subsubsection{Definition of Barriers}

Apart from market failures, the implementation of RES-E technologies is also hampered by the existing political framework, which often puts fossil fuels at an undue advantage over RES-E. A primary distortion results from the improper design of the EU ETS. The emissions cap set as well as the resulting allowance price do not reflect the true damage produced by $\mathrm{CO}_{2}$ emissions, i.e., fossil fuels do not bear their full social costs [15]. Another essential characteristic of emissions trading schemes, in contrast to taxes, is a volatile emissions price [53]. In the EU ETS, price volatility has been significant in recent years [54,55]. Volatility increases the uncertainty (and reduces the profitability) of investments in new generation facilities and technologies, including those in the RES-E sector [56]. This is aggravated by the fact that the adjustment of the emissions cap from period to period is subject to a political bargaining process and per se unknown. Consequently, the EU ETS is unlikely to set sufficient long-term incentives to promote the necessary technology transition in the energy sector [15,57].

Apart from the EU ETS, other policy instruments also favour non-renewable energy sources. Substantial subsidies have been and are paid for domestic coal production within the EU. Nuclear energy technologies have benefited from state-funded security measures, incomplete participation in disposal costs and insufficient liability rules in the event of a nuclear accident [58]. Furthermore, research in fossil and nuclear energy technologies has profited from immense governmental support [18].

Finally, barriers to RES-E deployment may also result from the sluggish liberalisation of the EU electricity market [59]. Dominant firms tend to invest mainly in incremental improvements of technologies that are currently in use rather than in fundamental technological change [60]. They may also use their market power to impede the entry of new competitors, operating, for example, RES-E installations [47]. Thus, there are fewer operating firms investing in innovation, which reduces the probability of a technological break-through [61].

\subsubsection{Policy Review}

We suggest abolishing the distortions set out by the political framework: tighten the emissions cap under the EU ETS, introduce a price collar for the allowance price, phase-out subsidies for fossil fuels, and spur electricity market liberalisation. However, such modifications are often not politically feasible [14]. For example, large fossil-fuel generators will continue lobbying against attempts to make the EU cap more stringent. Given these insights, existing RES-E support schemes are also useful and warranted as second-best means to compensate for a politically unequal treatment of energy technologies. 


\subsection{Community Acceptance}

\subsubsection{Definition of Barriers}

Low community acceptance of RES-E projects can be a further barrier. Most concerns relate to planning permissions for renewable energy facilities [62], but increasingly also to associated infrastructure, especially grids [63]. Local opponents, residents who thwart such projects, are often accused of NIMBYism and being emotive [64]. The "Not In My Back Yard" syndromes and Locally Unwanted Land Uses (or LULUs) have mainly been associated with wind farms [65-68], but also with biomass power plants [69-71], and even off-shore wind energy [72-74].

It is argued that, when NIMBYism prevails, planning consent for RES-E projects is less likely. But NIMBYism can be a misleading explanation for opposition against renewables [68]. Research often glosses over normative assumptions [75] and epistemology of acceptance issues [73,76]. Specific planning rules can determine to what extent aspects of acceptance influence decisions on planning consent [77,78]. Often, also more informal factors determine acceptance, including awareness and understanding of projects [65,73], fairness and trust [68,79,80], ownership of projects [78,81], scale and type of technology, or environmental concerns [65,82,83]. Acceptance appears highly context dependent [77,84]. Some, nevertheless, argue that acceptance relies on participation of local communities and stakeholders in the planning process [85-87], financial benefits or benefits in kind to local residents $[81,88,89]$ and stable supportive networks [86].

\subsubsection{Policy Review}

Community acceptance of RES-E projects depends on how they are promoted and who is investing. FIT systems have resulted in a large investor base and strong local ownership of RES-E plants in many countries [27], because they combine investment certainty with low transaction costs for RES-E developers [25,36,90]. In Denmark and Germany local farmers or cooperatives are responsible for large shares of FIT supported RES-E [27,78,91]. Opportunities to participate also financially in RES-E projects can raise a community's acceptance of RES-E facilities and reduce deployment costs $[27,52,77,92]$. Such benefits are not provided by quota systems under which investment decisions are subject to greater uncertainty and organisational efforts. Investors have to gather information about all competitors and their future investments to develop scenarios for future quota prices [38]. The necessity to trade quotas is a further barrier to local ownership, as required organisational learning favours large-scale investors and utilities. These are significant entry barriers for small-scale investors and explains why the number of investors can be relatively low $[25,38,93,94]$.

However, community acceptance of RES-E projects not only depends on RES-E support schemes. Opposition can have various reasons and requires contextually sensitive approaches for their resolution. If selfish NIMBYism can be identified as a core reason in a locality where a project at stake would generate a positive social net benefit, this benefit can be used to compensate those who suffer costs [95]. But care has to be taken. It is suggested that financial compensation can crowd-out motivation for hosting locally detrimental, but socially beneficial facilities [96]. Other studies point out that financial compensation often lacks acceptance and compensation should be in terms of local public goods [97]. Such compensation in kind can, however, exacerbate local opposition [85,88]. 
Financial compensation through tax revenues and shares in projects may be more appropriate $[78,89]$. Other measures proposed to identify optimal host regions or communities and necessary compensation payments, like auctions [98-100] and mechanism design approaches [101,102] find little consideration. They abstract from essential geographic conditions, like wind, sun, land or local demand and again, they can crowd-out community motivations to support RES-E more generally [96].

Alternative siting or some form of compensation is generally necessary when RES-E projects face opposition. Successful development seems likely when including (potential) opposition in early planning stages. Motivational crowding-out and appropriateness problems of compensation measures can be avoided, when the measures are designed in participation with the affected parties. Largely successful are projects managed and financed by local citizens, which are popular in Denmark and Northern Germany [78]. But transparent and participative planning and decision-making is essential for achieving acceptance [73]. Legal conflict-resolution instruments, such as zoning, permits or compulsory acquisition of land can be used [103]. They may, however, provoke further resistance, if participation is lacking or the procedures themselves are not accepted. Zoning of priority areas for RES-E facilities may imply costly governance of local participation, but can save costs inflicted by opposition in subsequent years.

\subsection{Planning Consent and Policy Commitment}

\subsubsection{Definition of Barriers}

Uncertainty and ex-ante transaction costs of gaining planning consent are major barriers for RES-E deployment [104-106]. Traditionally, spatial development plans preferred centralized (fossil-fuel) over spatially disperse (RES-E) energy generation projects [47]. Complicated and lengthy planning procedures, often involving many different authorities, imply larger (ex-ante) per-unit costs for small-scale RES-E projects than for large-scale fossil-fuel investments [3,5,34,105]. Uncertainty about future modifications of support schemes and other legislation around RES-E facilities, such as technical standards, can also deter RES-E investors and particularly suppliers of equipment $[3,38,52]$. Technology needs time to be developed and needs to comply with future legislation. Changes in legislation can lead to higher compliance and input costs in the future, which is mainly a concern for input-intensive bioenergy. Costs of compliance with planning consents, however, is much less likely to change during the lifespan of a project, if consents are legally secure.

\subsubsection{Policy Review}

Removing these barriers can lead to greater deployment of RES-E through clearer and more rapid planning procedures, which can be stemmed by smaller scale investors [78,89]. Such procedures would also benefit large-scale projects, which compete more directly with fossil fuels. Many RES-E projects, however, can be scaled down to units economically feasible for small investors. This could lead to a larger investor base, which in turn can improve community participation and acceptance (see Section 3.4.) and possibly lead to more liquidity and thus a lower return on investment required to access bank loans at low interest (see Section 3.3.). 
To improve inappropriately designed planning institutions for example those in the past in France or Greece $[5,106,107]$ many more detailed measures are conceivable. For example administrative charges can be reduced, more transparent guidelines be given, environmental impact assessments be more standardized, shorter minimum response periods for planning authorities be introduced and clear responsibilities be given to planning authorities, combined with a one-stop contact point for applicants. Many such initiatives have been taken at various levels in the EU, but are not implemented in all member states $[105,106]$.

Increased RES-E deployment and a growing RES-E industry require stable legal environments and credible support schemes and explicit long-term targets credibly backed by the government $[31,49,91,108]$. Backing by governments, stability of support schemes and legal security has been mixed across the EU [105] and could be improved in the future, especially when member states also credibly commit to each other.

\section{Grids}

\subsection{Lack of Network Capacity}

\subsubsection{Definition of Barriers}

Grid extension has not caught up with the boost of RES-E capacities and quantities. Existing grids are increasingly reaching their capacities in transmitting RES-E [109]. A lack of network capacity can become a barrier to new projects. Furthermore, even if capacity is available, significant cost of network connection, in particular for offshore wind, can be a significant barrier to RES-E deployment if it has to be financed by project developers [109].

The transformation towards an electricity system with high shares of RES-E requires significant transmission network expansion. The European transmission system operators project a need for $35,300 \mathrm{~km}$ of new lines until 2020. 20,000 km are driven by RES-E integration (part of these lines also serve other objectives such as security of supply or European Market Integration [110]). The projected investment costs are €23-28 billion [110]. Offshore grids are projected to cost an additional $€ 70-80$ billion [111].

One part of the problem is that good locations of RES-E are often located in rural and peripheral areas. In Germany, for example, good wind sites are located mostly in the North while most load centres are in the South and West. This requires power to be transported over large distances and is projected to cause transmission congestion if lines are not expanded [110].

Similarly, distribution networks require massive investments to accommodate decentralized RES-E since networks have not been built to feed electricity back to higher voltage levels; conventional plants usually feed in directly to high-voltage levels [112].

Two further problems are associated with the fact that network investments are carried out by regulated network operators and refunded via network charges. First, regulation has to provide sufficient investment incentives which might not be the case under incentive regulation, the current dominant regulatory scheme (see Section 4.3.). Second, investments should be efficient. Network operators need incentives to avoid unnecessary investments. Otherwise, customers, who finally pay for investments 
via network charges, will be unduly burdened. Furthermore, in the sense of achieving high shares of RES-E in the power system, those lines that bring most renewable capacity online should be built first.

A coordination problem between network and generators further aggravates network planning. The investment need triggered by new connections is dependent on the network topology. While some sites trigger investments, location at others can defer investment needs. An example can be local generation that fulfils local demand and thereby avoids the need to supply from distant generators over a congested line. Optimal network investment depends on generator locations [32,37,38,113]. A lack of coordination may lead to suboptimal investments.

Efficient network investment becomes even more important when investment need is high and construction of new lines additionally suffers from other problems such as investment incentives under regulation (see Section 4.3.), a lack of social acceptance (see Section 3.4.) and complex permitting procedures (see Section 3.5.) [110]. These restrictions at the network level draw into question whether the RES-E quantities necessary to reach EU targets can actually be provided within the short term.

\subsubsection{Policy Review}

RES-E support policy ensures generator network access (guaranteed connection, see also Section 4.3.). This is accompanied by an obligation of the network operator to expand the network in case capacity is insufficient to fulfil RES-E connection request or in cases where RES-E generation needs to be curtailed (see Section 4.2.). Such unconditional network expansion might be inefficiently expensive [114] and thereby hinder more beneficial investments.

The problem roots in a lacking system perspective both on the generation and the network side. Generation, demand, and network are interconnected. Effects of new connections depend on the local network conditions and can be either positive or negative [115]. Obviously there might be a trade-off between location quality from the generator perspective and the network perspective.

On the network side, scenarios that calculate required network extensions to fulfil renewable deployment targets can indicate such trade-offs between different network-generation constellations (see Section 6.1.). They are crucial for efficient system development and prioritization of investments and provide guidance to network operators.

On the generation side, network cost allocation is an important market based instrument to guide network connection and utilization. Both connection fees and system charges (if applied to generators) can be used to promote RES-E investments where its social value is highest, e.g., close to load centres. Network operators are required to connect RES-E (guaranteed grid access, see Section 4.3.), but network charges can be a tool to direct connections to more suitable places from the network perspective and thereby reduce the required investments [116,117]. Differentiated network charges can even promote distributed generation (DG) projects by rewarding their potential benefits for the system [118].

Network charges include connection charges recovering the investment cost for the connection and use of system charges that recover the operational network cost. Connection charges can be shallow or deep. While the first allocates only direct connection cost to the connectee, the latter also passes on costs that result from the connection deeper in the network such as upgrading a transformer. Deep charges are considered more cost-reflective. However, they are fraught with serious problems concerning 
the determination of non-discriminatory fair charges [119]. Most European countries today apply shallow charging, but some countries still apply variants of deep charging. While this is sometimes seen as a measure to signal network scarcity to generators, it may unfairly hinder RES-E projects. This is particularly the case if charges are intransparent or subject to negotiation, as for example in Austria or Greece [120]. From this perspective, shallow charges should be preferred. Guaranteed feed-in, priority access rules and other feed-in regulation should acknowledge the fact that it is not necessarily efficient to dimension grid access to net installed capacity, e.g., of a wind farm, if full load is only reached during few hours of a year. Curtailment of a few per cent of annual production makes sense if in turn grid investments can be significantly reduced. Implementation can be, e.g., via voluntary agreements between network and RES-E operators that compensate curtailment where it is allowed by the institutional framework $[121,122]$.

For shallow charges, the cost for grid investments has to be recovered via network use of system charges from generators and consumers. Some countries charge both generators and load, e.g., in the case of UK with a distribution of 27:73, the so called generation-load-split [123]. Charges for transmission use of system in the UK are already locationally differentiated; for distribution locational signals are currently introduced [124]. In Germany, however, generators are not subject to system charges [125]. This gives away a potential element to send signals on available network capacity to generators. In general, the degree to which network operators can use network charging to steer connections is limited today [117].

\subsection{Intermittency, Controllability and Securing Peak Capacity}

\subsubsection{Definition of Barriers}

Non-interrupted supply, power quality and stable frequency are public goods in the electricity system. Renewable energy supply is intermittent and dependent on external factors such as wind speeds and solar radiation. The volatility of RES-E supply in combination with reduced controllability of RES-E, particularly if generated by wind turbines or photovoltaics, is nonetheless highlighted as a major drawback. Growing shares of RES-E raise two problems:

- Matching supply and demand (market level—hourly perspective): In periods with high RES-E generation, supply may exceed demand, creating negative electricity prices in the spot market [126]. On the other hand, costly back-up capacity has to be held available for periods with low RES-E generation. Thus, RES-E volatility reduces the predictability of energy supply and increases the costs of electricity generation. This market based perspective focuses on hourly balance.

- Safe network operation: With preferred grid access of renewables, grid operators are challenged by peak renewable input. The additional variability at the production side is a challenge for securing stable voltage across grids. To accommodate unpredicted fluctuations, grid operators need to provide increased reserve power on the balancing market. In periods of very high feed-in, electricity supply may occasionally exceed the amount that can be safely absorbed while still maintaining adequate reserves and dynamic control in the system; energy production 
may need to be curtailed. This system operation perspective focuses on the balance of supply and demand on a second to minute basis.

A RES-E high electricity system requires higher degrees of flexibility to average out generator fluctuations. A lack of flexibility can therefore become a barrier for RES-E growth. A further problem is the limited recognition of RES-E contributions to power system stability and security in network security standards [118].

\subsubsection{Policy Review}

Variability in the electricity system is not a new phenomenon. Operators are skilled in handling predicted and unpredicted fluctuations in demand (e.g., an extra-time in a World-Cup final). With increased forecast quality of renewable energy supply in both hourly and day-ahead time frames, operators can control fluctuating energy supply more easily. Local variations in energy supply are averaged out on a system-wide level, provided that transmission capacity is sufficiently high. Still, problems may occur at the local level. Storage capacities (pumped storage, heat pumps, water supply reservoirs) and demand-side management can accommodate peaks in energy generation and also enable distribution network operators to securely manage local imbalances (see Section 5.) [126].

First steps are made to incorporate RES-E into system management and ancillary services. This includes granting network operators certain control rights on generators. System operators are allowed to deviate from priority access for RES-E for stability. However, they have to take corrective measures to avoid curtailments and report those actions to the regulatory authority reasons [127]. A further instrument to improve network integration of RES-E is demanding technical minimum requirements from generators. Sufficiently stringent specifications are required to allow the system to operate safely and securely even at high RES-E penetration rates. At the generator side, specifications should not be prohibitively costly since RES-E generators are often much smaller than traditional synchronous generators and different technology makes it more difficult to fulfil certain specifications (e.g., photovoltaics installations that produce DC power). Some countries require RES-E installations to fulfil minimum standards regarding controllability and system stabilizing capabilities (e.g., Germany for wind, new combined-heat-and-power installations [128] and with the new FIT also for photovoltaics). Installations that decide not to install the respective technology are not entitled to receive a FIT. This is a pragmatic, low transaction cost solution to enable network operators to manage the increasingly complex system and thereby helps to bring the capacities on line.

Market integration of RES-E can also be promoted by the design of support schemes for RES-E generation. For FITs, premium tariffs, which are paid to RES-operators in addition to electricity market price, are usually preferred over fixed tariffs, which are irrespective of the prevailing electricity price. Premium tariffs require operators of RES-E plants to market their electricity and are therefore expected to ease the transition towards an electricity market without RES-E support $[5,129]$. Moreover, they set incentives for a higher demand orientation of RES-E generation where possible [130]. In the UK, in the context of the Electricity Market Reform Package, premium tariffs and contracts for differences are currently discussed to support low carbon generation [131,132]. However, there may be important trade-offs with respect to other barriers. Compared to fixed tariffs, premium tariffs increase transaction costs and reduce investment certainty. Thus, they are less suited to overcome 
capital-market restrictions (see Section 3.2.) and acceptance problems (see Section 3.4.) associated with RES-E generation [108,129,133,134]. This is empirically reflected in higher RES-E deployment costs, which were found, for example, to be $10-40 \%$ higher under a premium tariff than under a fixed tariff from 2004 to 2006 in Spain [108]. Consequently, premium tariffs should only be considered for RES-E technologies which can actually respond to time-variable price signals, such as biomass or hydro power, while for unresponsive technologies like solar and wind a fixed tariff is preferable. The exposure to time-variable market prices will not have a sufficiently positive effect to offset the increased transaction and risk costs of a premium [135]. However, premium tariffs can be specifically designed to mimic most properties of fixed tariffs without losing their market integration appeal. The premium can be allowed to increase with decreasing electricity prices, as in the Netherlands, or be coupled with a price floor and cap, as in Spain [130]. Alternatively, or for a transition period, RES-E generators could also be allowed to choose between both approaches (as in Spain) [133].

\subsection{Market Power and Regulation}

\subsubsection{Definition of Barriers}

Transmission networks are natural monopolies, due to economics of scale and scope and because of the physical properties of electricity that require network management to be integrated for stability reasons. To prevent the abuse of market power, monopolist network operators are usually regulated. Since transmission capacity, connection policies, system management, and grid codes are crucial for the deployment of RES-E, appropriate regulation is key for the success of renewable energy integration.

On the one hand, vertically integrated companies that own both generation assets and the network have an incentive to use grid access policies as an entrance barrier for new competitors, including RES-E. Thus insufficient regulation can be a barrier to RES-E deployment. In the European Union, electricity generation and transmission were undertaken by vertically integrated monopolies until the 1980s. Since the 1990s, policy makers have made considerable effort to solve this issue, but further steps might be needed [136].

On the other hand, due to geographical specificity (see Section 4.1.) and intermittency (see Section 4.2.), a RES-E-heavy electricity system has different demands towards the network than a conventional system, e.g., a different topology and different approaches toward stability and management. The transformation of the network requires large investments and new and unproven technologies. Consequently, a regulatory framework is needed that supports investments and innovation, while existing regulation often focuses on efficient operation [137]. Thus, the wrong regulatory approach can also be a barrier to RES-E.

\subsubsection{Policy Review}

Two major policies have been applied to ensure that grid access policies are not used as entrance barriers for RES-E. First, as part of the third energy package, the European Union pushed for unbundling generators from network operators [136]. But even under successful unbundling, established contacts between grid operators and large utilities may still favour the latter. Second, RES-E generators were granted guaranteed connection and priority feed-in. The latter has been recently incorporated into 
European legislation [127]. Also, network operators are required to publish timelines for processing connection requests, which reduces uncertainty. Taken together, these policies seem to be quite efficient measures to avoid discrimination, but they need to be applied consistently throughout Europe, which is currently not the case: Significant obstacles remain and the EU still finds that "in general, average lead times for grid connection were very high representing a significant bottleneck" [105].

The second barrier, the type of regulatory framework itself, has received much less attention from policy makers up to now. Incentive regulation, which is the dominant regulatory approach today, has been developed in the context of existing grids with limited investment need. The focus of incentive regulation lies in efficient operation of an existing network. In view of the large grid investments required for RES-E integration and the strong need for innovative technologies such as DC lines, sea cables, smart grids, but also new approaches to voltage support and regulating power, this might become a barrier for RES-E development. For example, traditional regulation of investment often does not account appropriately for the risk due to new technologies. Hence, new approaches aim to advance the regulatory framework to promote sufficiently large investments and set the right incentives to innovate and to apply new technologies $[138,139]$. This may include adding elements to the existing incentive regulation such as an investment or innovation bonus or granting higher returns to account for the risk of less well established technologies. Furthermore, policy should support new technologies as providers of ancillary services and lower entrance barriers to ancillary service markets for RES-E generators, consumers, and other technologies.

Additionally, instruments outside regulation may be needed to foster R\&D such as the low carbon network fund in the UK. In the long run, a redesign of the regulatory approach may be necessary to take account for the aim of achieving a low carbon electricity system. The UK has made this step with the implementation of the RIIO model (Revenue = Incentives + Innovation + Outputs). This new regulatory approach includes sustainability as objective and recognizes a high need for system transformation [140]. However, the operationalization of the sustainability objective and the performance of the new regulatory system as well as of the electricity market reform that is underway have still to be seen.

\subsection{Cross-Border Externalities}

\subsubsection{Definition of Barriers}

Transmission networks are usually managed by transmission system operators (TSOs) that are responsible for a certain geographical region (control area), typically of the size of countries or smaller. The system operators that own the network assets within the control area are legally responsible for frequency and voltage stability and uninterrupted supply, and decide upon investment in this region. They are typically regulated by national authorities. Due to locational specificity (see Section 4.1.) and the fluctuating patterns of solar radiation and wind (see Section 4.2.), RES-E-heavy systems require more long-distance transmission capacity beyond national borders and control areas (interconnectors). This poses two problems.

In the past, TSOs have often looked at their area as a largely self-contained system. Interconnectors to neighbouring TSOs were meant to ensure supply in case of emergencies. Long-term investment 
planning and system management procedures have to be made consistent across (several) TSOs. In other words, limited TSO cooperation can be a barrier for RES-R.

Regulators are usually national authorities which plausibly can be expected to maximize national welfare. However, both national and cross-border transmission projects usually exhibit externalities that affect other countries. For example, increasing the capacity of a North-South line in Belgium most probably increases the possibility to transport electricity from North to South Germany. The main reason for externalities in electricity networks is that the electrical current is determined by Kirchhoff's laws and can hardly be influenced by the system operator. That means that a larger in-feed of electricity in North Germany affects the flow on all lines in the synchronous area, and probably increases the North-South-flow through Belgium. Relaxing a bottleneck in Belgium thus allows a more efficient use of German lines, which is a positive externality. It is highly plausible that regulators do not take the external effects into account, and therefore underinvest in transmission. Since RES-E generation is more location-specific than conventional generation, and thus has to rely more on longdistance transmission capacity, it is more affected by that externality. International (cross-border) transmission projects have the additional difficulty that even the direct benefits appear in more than one country. Thus national approaches to regulation are a barrier to RES-E deployment.

\subsubsection{Policy Review}

Continued cooperation between TSOs is needed to ensure consistency in long-term investment planning, allow market coupling and other forms of market integration, and make grid codes compatible to facility cross-border trade of ancillary services. This process is under the way, with the industry association European Network of Transmission System Operators for Electricity (ENTSO-E) playing an important role. Well known examples include the Ten-Year Network Development Plan. However, still much remains to be done [110] and incentives for increased cooperation need to be fostered.

Not only TSOs need to cooperate, but also regulators and governments need to take an international perspective. National regulators maximizing national welfare ignore positive externalities and lead to underinvestment in interconnections. To ensure efficient transmission investment it is important to take benefits into account that occur outside the control area and outside the country where the investment takes place. The recently established Agency for the Cooperation of Energy Regulators (ACER), the Council of European Energy Regulators (CEER) as well as direct EU funding for cross-border transmission projects are important first steps. What is needed, however, is a clear and explicit commitment of regulators to focus on European welfare instead of national welfare. To make this feasible, rules and procedures for redistributing benefits across control areas and countries need to be established. For example, if German generators and consumers benefit from transmission investments in Belgium, they should contribute to financing that investment. In the end an institutionally well-established European regulator might be needed. 


\section{Storage and Demand Response}

\subsection{Economic Incentives}

\subsubsection{Definition of Barriers}

A system with large share of fluctuating RES-E (see Section 4.2.) also requires more flexibility on the demand side. Today, the incentives to store electricity and adjust demand by reducing or shifting consumption over time are limited by two major barriers. First, price signals to consumers are weak. While wholesale prices change every hour, tariffs for small customers in most European countries are fixed for weeks to years, eliminating incentives to adjust consumption [141,142]. Furthermore, wholesale prices represent only $30-50 \%$ of household electricity prices, the rest being grid fees and taxes. These components do not fluctuate at all, although there are good reasons why they should. Empirical evidence as reviewed in [143] indicates that even household consumers respond considerably price-elastic.

Second, demand response and storage applications can often provide significant power, but only limited energy volumes: they are "short-time applications". That makes them well suited for ancillary service markets [144]. However, entrance barriers to these markets often prevent participation. Relevant barriers include the form of grid codes, ancillary service market design, market power in these markets, or regulation.

\subsubsection{Policy Review}

To foster price signals for consumers, three sets of policies are needed: First, the appropriate infrastructure needs to be in place (see Section 5.2.). Second, legal barriers to dynamic pricing such as price regulation should be removed [1]. Finally, making network charges and taxes time-variant, for example proportional to the spot price, would increase incentives significantly. It seems plausible to let the value added tax fluctuate with the price of the underlying good on logical grounds. Also, there is no good reason to apply a constant grid fee while costs are driven by infrastructure designed for peak demand.

In addition, overcoming entrance barriers to balancing power markets can be an important means to support storage and demand applications. Improvements can be achieved by lowering the minimum bid size in balancing markets and adjusting pre-commitment requirements to incentivize demand side participation [145].

\subsection{Lack of Communication Infrastructure}

\subsubsection{Definition of Barriers}

Information and communication technologies are expected to support electricity systems with high shares of renewables and an active demand side. Smart meters (which enable advanced functionalities such as real-time pricing and remote meter reading; they may also enable more functions such as remote control or visualization of consumption profiles) and communication infrastructure provide for bi-directional information exchange and enable new services such as dynamic pricing or demand side 
management that support a flexible electricity system. These developments are commonly referred to as smart grids.

One barrier for the development of smart grids and the activation of the demand side can be the lack of smart meters since these are considered prerequisite for the introduction of time-variant pricing. At the same time, the absence of dynamic tariffs prevents the roll-out of smart meters [1]. But there is a more fundamental barrier to infrastructure development. Similar to generation technologies, knowledge spillovers may also result in suboptimal investment in metering and grid technologies and in smart appliances. Moreover, these technologies are also characterized by increasing returns, i.e., costs are relatively high at the moment but likely to decrease as the production of smart meters increases or the number of users of the underlying communication network rises [146].

Finally, there may also be institutional limits to storage and demand response. The classical investor-user dilemma in the housing sector, which has often been highlighted as an important barrier to energy-efficiency investments - split incentives between landlords who invest in energy technologies and tenants who pay for electricity bills - is also likely to hinder the adoption of demand-side storage and management technologies [147].

\subsubsection{Policy Review}

A large set of policies can support infrastructure roll-out, from appropriate network regulation to smart meter requirements, $R \& D$ funding, and industry standardization. Up to now, instruments to support storage and demand response are rare. Some support comes within the framework of smart grids. European and national R\&D programs support smart grid research (e.g., Framework Programme 7 allocates $€ 1.5$ billion to smart grids microsystems and corresponding information and communication technologies, and electro-mobility), and several pilot projects have been realized (e.g., CELL project, FENIX, e-Energy). The step from pilot to large-scale realization is still missing. Furthermore, the focus of the different projects varies widely from distribution automation over dynamic pricing to demand side management. Smart meters as a sub-part of smart grids are supported in the EU's third energy package that aims to "encourage the introduction of intelligent metering systems" [148]. Some countries opted for a complete roll-out of smart meters (e.g., Italy, Sweden) while others have not (e.g., Germany). Even though smart meter technology can be used to make the entire system more efficient, the network and system benefits seem to be insufficiently on the agenda (for the Netherlands and Great Britain network issues did play a role in motivating role out; in Sweden and Italy network issues did not seem to play a relevant role [149]). Split incentives remain a problem.

If the barriers and market failures mentioned cannot be removed, it can be efficient to rely on second-best policies and support demand response and storage directly through subsidies. These incentives could be combined with the RES-E support scheme to motivate plant operators to provide flexibility along with the intermittent power source. As important as correct incentives is probably support for the development of communication infrastructure as a precondition for storage and demand response. Smart meters, intelligent distribution grids, or e-mobility infrastructure may need direct support since market based roll-out may be rather slow [149]. 


\section{Integration of the Electricity System}

The previous assessment of RES-E policies in the EU has provided two insights: (1) policies have been implemented rather uncoordinated, but with a clear focus on generation; and (2) policy design and implementation have been primarily within the responsibility of Member States under an only weak and rough common EU framework. A much stronger integration of RES-E policies both across the EU and across the sectors (generation, grid, and storage and demand response) is required for integrated infrastructure provision (also overcoming cross-border grid externalities) and geographically efficient renewable energy deployment. An EU-wide coordination of RES-E support schemes can realize cost-saving potentials from clustering RES-E installations at beneficial sites throughout the EU. In the following, two important measures will be discussed, which should form part of such a planning approach: (1) A European Scenario for the electricity system and (2) a EU-wide harmonisation of RES-E policies.

\subsection{A European Scenario for the Electricity System}

A European scenario for the electricity system should comprise consistent and spatially explicit projections for electricity demand and supply with detailed deployment plans for each renewable source, storage capacities, flexibility measures and grid expansion-both within and across member states. It has to be detailed on the short term (one to five years), but must also incorporate a long-term view (15-20 years) to identify bottlenecks and opportunities at an early stage and help prevent stranded investments. In this way, the scenario reveals needs for investment and new policy instruments at an early stage. The detailed deployment plans can be realized through a FIT with a breathing cap (see Section 3.1.2.).

How to choose and develop the European scenario? Starting from a range of possible scenarios with different assumptions on major decision variables, such as the implementation of transnational integration or the approach of variability-balancing, the adequate scenario has to be identified by the governments through trading off the respective pros and cons. Widespread endorsement will only be achieved if the scenario development process is transparent, rests on a solid scientific basis and moreover allows for participation of all stakeholders. As the process has to be continuously updated whenever new information on technical developments or cost parameters becomes available, it might be useful to institute a special agency dedicated to scenario development.

The necessity for a clearly defined, independent and transparent process can be exemplified on the German experience of projecting future grid requirements. This is currently accomplished by a small agency that outsources the calculations of future scenarios and grid requirements to the incumbent energy companies and grid operators [150], thus risking conflicts of interest. The resulting studies are criticised for their lack of transparency [151]: Neither detailed data nor modelling procedures are made public which disables any scientific review. Also, the study is based on a short-term view without considering the long-term RES-E-targets and hardly accounts for the European dimension.

An EU planning agency could deliver such a scenario. Currently, most Member States have differently structured energy markets and regulating authorities, and have their own ideas on future energy markets. A pragmatic way towards an EU-wide energy scenario would be the development of 
national scenarios in each member state within the consistent framework outlined above. The national authorities developing the scenarios should focus on strong coordination and collaboration between each other, so that the scenarios are coherent across the EU. The EU planning agency could then bring the scenarios together and foster harmonisation of these scenarios, and also suggest integrated EU-wide scenarios.

\subsection{Harmonisation of Policies}

Based on the chosen scenario, the common EU framework for RES-E policies can be advanced. The policy process has to account for positive as well as negative effects of EU-wide policy harmonisation and result in a feasible compromise. This is discussed here exemplarily for RES-E generation. A harmonisation of remuneration rules for RES-E generation may increase the cost-effectiveness of RES-E support. It creates a larger uniform market for the deployment of RES-E technologies, enabling economies of scale. It can lead to an optimized spatial allocation of RES-E plants with clusters in particularly beneficial areas (photovoltaics in the south, wind turbines in coastal areas of the north), which reduces generation costs. Moreover, it may allow for an EU-wide burden-sharing of remuneration costs [5,129,152-154]. However, there are also limits to harmonisation. Most importantly, possible trade-offs between efficiency gains from centralized generation and additional costs associated with grid extension and long-distance transmission have to be considered. Potential gains cannot be realized as long as cross-border grid capacities are insufficient and the EU-wide electricity market is not properly liberalized and integrated [108]. In addition, an EU-wide harmonisation disregards national and local benefits of RES-E generation, such as national supply security and regional economic development [5,129]. Finally, harmonisation efforts may even hinder the deployment of RES-E. Large-scale centralized generation may increase opposition against RES-E installations (see Section 3.4.). The transition period necessary for harmonisation also increases investment uncertainties [5,155]. Consequently, harmonising basic principles and methodologies for designing remuneration schemes is better than harmonising in detail, e.g., the actual level of remuneration for a specific technology.

\section{A Transition to Sustained Carbon Lock-Out}

A European carbon lock-out characterised by RES-E deployment requires coordinated action at multiple levels [156], involving the removal of the barriers with the policies listed in Table 1 . It would be part of a larger socio-technical transition with uncertain trajectories of institutional and technological change, but also windows of opportunity [157,158]. To create momentum, opportunity for entrepreneurial [159] and policy learning [160] needs to be ensured [161], which is needed because we do not have enough knowledge about future policy challenges of RES-E deployment [162]. The transition to RES-E would be a bumpy road, if we do not align policies and networked technology niches to match generation of RES-E with demand, storage and capacities of grids and other infrastructure [163]. 
Table 1. Specific barriers constituting a carbon lock-in and corresponding policies.

\begin{tabular}{|c|c|c|c|}
\hline & $\begin{array}{l}\text { Barrier constituting } \\
\text { carbon lock-in }\end{array}$ & Policies in place & Policies for carbon lock-out \\
\hline \multirow{5}{*}{ 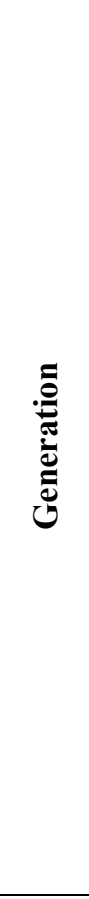 } & $\begin{array}{l}\text { Learning and knowledge } \\
\text { spillovers }\end{array}$ & - Feed-in tariffs or quotas & $\begin{array}{l}\text { - Feed-in tariff (substituting quotas) } \\
\text { with Breathing Cap }\end{array}$ \\
\hline & Capital market restrictions & - Feed-in tariffs or quotas & - Feed-in tariff (substituting quotas) \\
\hline & $\begin{array}{l}\text { Uneven political playing } \\
\text { field }\end{array}$ & - None & $\begin{array}{l}\text { - Tighten the of the EU Emissions } \\
\text { Trading Scheme } \\
\text { - Implement a price collar for the EU } \\
\text { Emissions Trading Scheme } \\
\text { - Phase-out fossil-fuel subsidies } \\
\text { - Spur market liberalisation } \\
\text { - Feed-in tariffs as second-best means }\end{array}$ \\
\hline & Community acceptance & - None & $\begin{array}{l}\text { - Foster local ownership (e.g., by } \\
\text { feed-in tariffs rather than quotas) } \\
\text { - Transparent and participative } \\
\text { planning and decision-making } \\
\text { - Clear and participative zoning }\end{array}$ \\
\hline & $\begin{array}{l}\text { Planning consent and } \\
\text { policy commitment }\end{array}$ & $\begin{array}{l}\text { - Attempts to handle planning more } \\
\text { clearly and quickly }\end{array}$ & $\begin{array}{l}\text { - One-stop contact points for investors } \\
\text { - Brief and binding approval periods } \\
\text { - Governments endorsing explicit } \\
\text { deployment scenarios }\end{array}$ \\
\hline \multirow{4}{*}{ 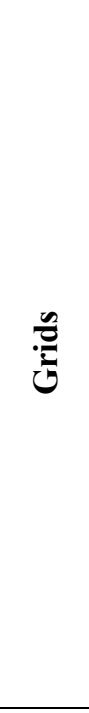 } & Lack of network capacity & - Partially deep connection charges & $\begin{array}{l}\text { - Shallow connection charges plus } \\
\text { differentiated network use of system } \\
\text { charges to provide locational signals }\end{array}$ \\
\hline & $\begin{array}{l}\text { Intermittency, } \\
\text { controllability and } \\
\text { securing peak capacity }\end{array}$ & - Technical requirements & $\begin{array}{l}\text { - Feed-in tariffs with premiums for } \\
\text { certain technologies } \\
\text { - Voluntary curtailment agreements }\end{array}$ \\
\hline & $\begin{array}{l}\text { Market power and } \\
\text { regulation }\end{array}$ & $\begin{array}{l}\text { - Unbundling } \\
\text { - Priority network access } \\
\text { - Timelines for processing } \\
\text { connection request } \\
\text { - Regulation of efficient operation } \\
\end{array}$ & $\begin{array}{l}\text { - Stronger regulatory incentives for } \\
\text { investment and innovation }\end{array}$ \\
\hline & Cross-border externalities & $\begin{array}{l}\text { - Cooperative planning of European } \\
\text { transmission networks by operators } \\
\text { - First attempts of cooperation } \\
\text { between national regulators }\end{array}$ & $\begin{array}{l}\text { - Foster cooperation between national } \\
\text { regulators }\end{array}$ \\
\hline \multirow[t]{2}{*}{ 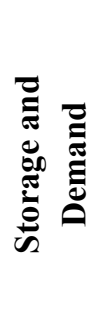 } & Economic Incentives & - None & $\begin{array}{l}\text { - Dynamic electricity pricing } \\
\text { - Time-variant grid fees and taxes } \\
\text { - Lower entrance barriers to ancilliary } \\
\text { markets, e.g., smaller bid size in } \\
\text { balancing markets }\end{array}$ \\
\hline & Technology & - Support for pilot projects & $\begin{array}{l}\text { - Large-scale support for infrastructure } \\
\text { development }\end{array}$ \\
\hline
\end{tabular}

Coordinated scenario development would help to create shared expectations among actors [164] and can facilitate investment and policy development at all levels from micro-generation to grid interconnectors. Accompanying activities are needed to create "self-fulfilling prophecies" $[165,166]$ : Advocates of RES-E have to increase their efforts to bring stakeholders together to plan the transition to a RES-E grid and storage infrastructure. Second, well-designed deployment-responsive FITs 
("breathing cap") automatically adjust the incentives according to deployment, thus increasing the likelihood of achieving the target scenario. Efforts have to be increased to encourage generation of RES-E in areas, where its deployment is limited, although potentially viable. FITs in combination with cheap loans and tax benefits to investors and local authorities seem particularly successful onshore, whereas offshore better surety for capital outlays and facilitation of planning permission seem paramount. Where RES-E is largely unknown or new technologies are to be tested, pilot projects could be considered. But participation of all potential advocates should be ensured to improve acceptance and encourage formation of more localized advocacy coalitions and networks of expertise that drive the transition to carbon lock-out. Attention should be given that these networks do not lock-in and discourage creativity [167].

At lower levels exchange among advocates can lead to technology, business and policy experimentation, which may diffuse as contextualized "best-practice" learning across Europe [168]. At higher levels, advocacy coalitions and emerging experts are likely to influence the politics of RES-E provisioning and larger scale investments into grids, storage and basic research [169]. Especially those, who are locally benefitting from generating RES-E, are likely to have vested interest in transforming national and trans-European grids and storage infrastructure to facilitate greater throughput of RES-E. They can push necessary investments. The emergence of expertise and advocacy networks can be sped up through facilitated exchange across Europe, e.g., by conferences, study tours, open-days or hearings. There is much to be learned from localised adjustments to grids and FIT systems, including the decision-making procedures on tariffs and developing technology. The match of infrastructure and storage with supply and demand of RES-E will be critical for sustained carbon lock-out. Pilot projects at smaller scale with more localized actors could be first steps for learning. Knowledge gained from such activities is strategically very valuable, as the last twenty years of RES-E deployment have shown [170]. At the national and European level, however, oversight, facilitation and exchange have to be ensured to avoid uneven costs and benefits of RES-E provision and distribution across Europe. Facilitators could be government departments, non-governmental organisations, researchers and RES-E business associations, but also individual entrepreneurs. Instead of working against each other, carbon lock-out requires concerted action of advocates at all levels, whilst allowing sufficient degrees of experimentation to capture future opportunities and to sustain the transition to full deployment of renewable electricity across Europe. To facilitate this transition, we have examined the barriers and how they could be overcome. Many areas require further research. In the meantime the ball is with other advocates.

\section{Acknowledgements}

We are grateful to Christian Breyer, Jan Christoph Goldschmidt, Moritz Riede and Johannes Widmer for helpful discussions of previous versions of this paper, and to three anonymous referees for their constructive comments. 


\section{References and Notes}

1. Edenhofer, O.; Pichs Madruga, R.; Sokona, Y.; Seyboth, K.; Matschoss, P.; Kadner, S.; Zwickel, T.; Eickemeer, P.; Hansen, G.; Schlömer, S.; von Stechow, C. IPCC Special Report on Renewable Energy Sources and Climate Change; Cambridge University Press: Cambridge, UK, 2011.

2. European Commission. COM (2008) 30: Communication from the Commission to the European Parliament, the Council, the European Economic and Social Committee and the Committee of the Regions: 2020 by 2020-Europe's Climate Change Opportunity; European Commission: Brussels, Belgium, 2008.

3. European Commission. COM (2011) 31: Renewable Energy: Progressing towards the 2020 Target; European Commission: Brussels, Belgium, 2011.

4. EUROSTAT Electricity generated from renewable sources. Available online: http://appsso.eurostat.ec.europa.eu/nui/show.do?dataset=nrg_ind_333a\&lang=en (accessed on 24 October 2011).

5. European Commission. SEC (2008) 57: “The Support of Electricity from Renewable Energy Sources" Accompanying Document to the Proposal for a Directive of the European Parliament and of the Council on the Promotion of the Use of Energy from Renewable Sources [COM (2008) 19 Final]; Commission Staff Working Document; European Commission: Brussels, Belgium, 2008.

6. Unruh, G.C. Understanding carbon lock-in. Energy Policy 2000, 28, 817-830.

7. Sinn, H.-W. The Green Paradox; MIT Press: Cambridge, MA, USA, in press.

8. Frondel, M.; Ritter, N.; Schmidt, C.M. Germany's solar cell promotion: Dark clouds on the horizon. Energy Policy 2008, 36, 4198-4204.

9. Frondel, M.; Ritter, N.; Schmidt, C.M.; Vance, C. Economic impacts from the promotion of renewable energy technologies: The German experience. Energy Policy 2010, 38, 4048-4056.

10. Shalizi, Z.; Lecocq, F. Climate Change and the Economics of Targeted Mitigation in Sectors with Long-Lived Capital Stock; Policy Research Working Paper; World Bank: Washington, DC, USA, 2009.

11. Davis, S.J.; Caldeira, K.; Matthews, H.D. Future $\mathrm{CO}_{2}$ emissions and climate change from existing energy infrastructure. Science 2010, 329, 1330-1333.

12. Sandén, B.A.; Azar, C. Near-term technology policies for long-term climate targets-Economy wide versus technology specific approaches. Energy Policy 2005, 33, 1557-1576.

13. Kalkuhl, M.; Edenhofer, O.; Lessmann, K. Learning or lock-in: Optimal technology policies to support mitigation. Resour. Energy Econ. 2012, 34, 1-23.

14. Lehmann, P.; Gawel, E. Why Should Support Schemes for Renewable Electricity Complement the EU Emissions Trading Scheme? UFZ Discussion Papers; Helmholtz Centre for Environmental Research-UFZ: Leipzig, Germany, 2011.

15. Matthes, F. Greenhouse Gas Emissions Trading and Complementary Policies. Developing a Smart Mix for Ambitious Climate Policies; Öko-Institut e.V.: Berlin, Germany, 2010.

16. Argote, L.; Epple, D. Learning curves in manufacturing. Science 1990, 247, 920-924. 
17. Church, J.; Ware, R. Industrial Organization A Strategic Approach; McGraw Hill: Boston, MA, USA, 2000.

18. Breyer, C.; Birkner, C.; Kersten, F.; Gerlach, A.; Goldschmidt, J.C.; Montoro, D.F.; Riede, M. Research and development investments in PV-A limiting factor for a fast PV diffusion? In Proceedings of the 25th European Photovoltaic Solar Energy Conference (WCPEC-5), Valencia, Spain, 6-10 September 2010.

19. IEA Experience Curves for Technology Policy; International Energy Agency (IEA): Paris, France, 2010.

20. Neij, L. Cost development of future technologies for power generation-A study based on experience curves and complementary bottom-up assessments. Energy Policy 2008, 36, 2200-2211.

21. Irwin, D.A.; Klenow, P.J. Learning-by-doing spillovers in the semiconductor in-dustry. J. Polit. Econ. 1994, 102, 1200-1227.

22. Lehmann, P. Climate Policies with Pollution Externalities and Learning Spillovers; UFZ Discussion Papers; Helmholtz Centre for Environmental Research-UFZ: Leipzig, Germany, 2009.

23. Jaffe, A.; Newell, R.; Stavins, R. A tale of two market failures: Technology and environmental policy. Ecol. Econ. 2005, 54, 164-174.

24. Held, A.; Ragwitz, M.; Haas, R. On the success of policy strategies for the promotion of electricity from renewable energy sources in the Eu. Energy Environ. 2006, 17, 849-868.

25. Mitchell, C.; Bauknecht, D.; Connor, P.M. Effectiveness through risk reduction: A comparison of the renewable obligation in England and Wales and the feed-in system in Germany. Energy Policy 2006, 34, 297-305.

26. Lipp, J. Lessons for effective renewable electricity policy from Denmark, Germany and the United Kingdom. Energy Policy 2007, 35, 5481-5495.

27. Toke, D. Renewable financial support systems and cost-effectiveness. J. Clean. Prod. 2007, 15, 280-287.

28. Fouquet, D.; Johansson, T.B. European renewable energy policy at crossroads-Focus on electricity support mechanisms. Energy Policy 2008, 36, 4079-4092.

29. Butler, L.; Neuhoff, K. Comparison of feed-in tariff, quota and auction mechanisms to support wind power development. Renew. Energy 2008, 33, 1854-1867.

30. Jacobsson, S.; Bergek, A.; Finon, D.; Lauber, V.; Mitchell, C.; Toke, D.; Verbruggen, A. EU renewable energy support policy: Faith or facts? Energy Policy 2009, 37, 2143-2146.

31. Haas, R.; Panzer, C.; Resch, G.; Ragwitz, M.; Reece, G.; Held, A. A historical review of promotion strategies for electricity from renewable energy sources in EU countries. Renew. Sustain. Energy Rev. 2011, 15, 1003-1034.

32. Haas, R.; Resch, G.; Panzer, C.; Busch, S.; Ragwitz, M.; Held, A. Efficiency and effectiveness of promotion systems for electricity generation from renewable energy sources-Lessons from EU countries. Energy 2011, 36, 2186-2193.

33. De Jager, D.; Klessman, C.; Stricker, E.; Winkel, T.; de Visser, E.; Koper, M.; Ragwitz, M.; Held, A.; Resch, G.; Busch, S. Financing Renewable Energy in the European Energy Market; ECOFYS: Berlin, Germany, 2011. 
34. European Commission. COM (2005) 627 Final: The Support of Electricity from Renewable Energy Sources; European Commission: Brussels, Belgium, 2005.

35. IEA. IEA Photovoltaic Power Systems Programme (PVPS): National Reports; International Energy Agency (IEA): Paris, France, 2011.

36. Del Río, P.; Gual, M.A. An integrated assessment of the feed-in tariff system in Spain. Energy Policy 2007, 35, 994-1012.

37. Kildegaard, A. Green certificate markets, the risk of over-investment, and the role of long-term contracts. Energy Policy 2008, 36, 3413-3421.

38. Wood, G.; Dow, S. What lessons have been learned in reforming the Renewables Obligation? An analysis of internal and external failures in UK renewable energy policy. Energy Policy 2011, 39, 2228-2244.

39. Bergek, A.; Jacobsson, S. Are tradable green certificates a cost-efficient policy driving technical change or a rent-generating machine? Lessons from Sweden 2003-2008. Energy Policy 2010, 38, $1255-1271$.

40. Ford, A.; Vogstad, K.; Flynn, H. Simulating price patterns for tradable green certificates to promote electricity generation from wind. Energy Policy 2007, 35, 91-111.

41. Mendonca, M.; Jacobs, D.; Sovacool, B.K. Powering the Green Economy: The Feed-in Tariff Handbook; Routledge: Oxford, UK, 2009.

42. Kreycik, C.; Couture, T.D.; Cory, K.S. Innovative Feed-In Tariff Designs that Limit Policy Costs; National Renewable Energy Laboratory (NREL), Golden, CO, USA, 2011.

43. Couture, T.D.; Cory, K.; Kreycik, C.; Williams, E. Policymaker's Guide to Feed-in Tariff Policy Design; National Renewable Energy Laboratory (NREL), Golden, CO, USA, 2010.

44. de la Hoz, J.; Boix, O.; MartÃ-n, H.; Martins, B.; Graells, M. Promotion of grid-connected photovoltaic systems in Spain: Performance analysis of the period 1998-2008. Renew. Sustain. Energy Rev. 2010, 14, 2547-2563.

45. Isoard, S.; Soria, A. Technical change dynamics: Evidence from the emerging renewable energy technologies. Energy Econ. 2001, 23, 619-636.

46. Menanteau, P.; Finon, D.; Lamy, M.-L. Prices versus quantities: Choosing policies for promoting the development of renewable energy. Energy Policy 2003, 31, 799-812.

47. Neuhoff, K. Large-scale deployment of renewables for electricity generation. Oxf. Rev. Econ. Policy 2005, 21, 88-110.

48. Walz, R. Interaktion des EU emissionshandels mit dem erneuerbare energien gesetz. $Z$. Energiewirtschaft 2005, 29, 261-270.

49. De Jager, D.; Rathmann, M.; Klessmann, C.; Coenraads, R.; Colamonico, C.; Buttazzoni, M. Policy Instrument Design to Reduce Financing Costs in Renewable Energy Technology Projects; ECOFYS: London, UK, 2008.

50. Toke, D. Trading schemes, risks, and costs: The cases of the European Union Emissions Trading Scheme and the Renewables Obligation. Environ. Plan. C 2008, 26, 938-953.

51. Lemming, J. Financial risks for green electricity investors and producers in a tradable green certificate market. Energy Policy 2003, 31, 21-32.

52. Dinica, V. Support systems for the diffusion of renewable energy technologies-An investor perspective. Energy Policy 2006, 34, 461-480. 
53. Schäfer, R.; Creutzig, F. Globale Treibhausgassteuer und Emissionshandel: Eine Frage des Instruments oder der Ausgestaltung? In Ablasshandel gegen Klimawandel? Marktbasierte Instrumente in der Globalen Klimapolitik und ihre Alternativen; Altvater, E., Brunnengräber, A., Eds.; VSA-Verlag: Hamburg, Germany, 2008; pp. 106-118.

54. Ellerman, A.D.; Joskow, P.L. The European Union's Emissions Trading System in Perspective; Pew Center on Global Climate Change: Arlington, VA, USA, 2008.

55. Hintermann, B. Allowance price drivers in the first phase of the EU ETS. J. Environ. Econ. Manag. 2010, 59, 43-56.

56. Betz, R.; Sato, M. Emissions trading: Lessons learnt from the 1st phase of the EU ETS and prospects for the 2nd phase. Clim. Policy 2006, 6, 351-359.

57. Ulph, A.; Ulph, D. Optimal Climate Change Policies When Governments Cannot Commit; Discussion Paper; Department of Economics, University of St. Andrews: St. Andrews, UK, 2011.

58. UBA Umweltschädliche Subventionen in Deutschland; Umweltbundesamt (UBA): Dessau, Germany, 2008.

59. Joskow, P. Lessons learned from electricity market liberalization. Energy J. 2008, 29, 9-42.

60. Grubb, M. Technologies, energy systems and the timing of $\mathrm{CO} 2$ emissions abatement. Energy Policy 1997, 25, 159-172.

61. Geroski, P.A. Innovation, technological opportunity, and market structure. Oxf. Econ. Paper 1990, 42, 586-602.

62. Wüstenhagen, R.; Wolsink, M.; Bürer, M.J. Social acceptance of renewable energy innovation: An introduction to the concept. Energy Policy 2007, 35, 2683-2691.

63. Devine-Wright, H.; Devine-Wright, P. Social representations of electricity network technologies: Exploring processes of anchoring and objectification through the use of visual research methods. Br. J. Soc. Psychol. 2009, 48, 357-373.

64. Cass, N.; Walker, G. Emotion and rationality: The characterisation and evaluation of opposition to renewable energy projects. Emot. Space Soc. 2009, 2, 62-69.

65. Devine-Wright, P. Beyond NIMBYism: Towards an integrated framework for understanding pub-lic perceptions of wind energy. Wind Energy 2005, 8, 125-139.

66. Haggett, C.; Toke, D. Crossing the great divide-Using multi-method analysis to understand opposition to windfarms. Public Adm. 2006, 84, 103-120.

67. Kaldellis, J.K. Social attitude towards wind energy applications in Greece. Energy Policy 2005, 33, 595-602.

68. Wolsink, M. Wind power and the NIMBY-myth: Institutional capacity and the limited significance of public support. Renew. Energy 2000, 21, 49-64.

69. Upreti, B.R. Conflict over biomass energy development in the United Kingdom: Some observations and lessons from England and Wales. Energy Policy 2004, 32, 785-800.

70. Jenssen, T. The good, the bad, and the ugly: Acceptance and opposition as keys to bioenergy technologies. J. Urban Technol. 2010, 17, 99-115.

71. Zoellner, J.; Schweizer-Ries, P.; Wemheuer, C. Public acceptance of renewable energies: Results from case studies in Germany. Energy Policy 2008, 36, 4136-4141.

72. Devine-Wright, P.; Howes, Y. Disruption to place attachment and the protection of restorative environments: A wind energy case study. J. Environ. Psychol. 2010, 30, 271-280. 
73. Haggett, C. Understanding public responses to offshore wind power. Energy Policy 2011, 39, 503-510.

74. Firestone, J.; Kempton, W.; Krueger, A. Public acceptance of offshore wind power projects in the USA. Wind Energy 2009, 12, 183-202.

75. Aitken, M. Why we still don't understand the social aspects of wind power: A critique of key assumptions within the literature. Energy Policy 2010, 38, 1834-1841.

76. Ellis, G.; Barry, J.; Robinson, C. Many ways to say "no", different ways to say "yes": Applying Q-Methodology to understand public acceptance of wind farm proposals. J. Environ. Plan. Manag. 2007, 50, 517-551.

77. Breukers, S.; Wolsink, M. Wind power implementation in changing institutional landscapes: An international comparison. Energy Policy 2007, 35, 2737-2750.

78. Toke, D.; Breukers, S.; Wolsink, M. Wind power deployment outcomes: How can we account for the differences? Renew. Sustain. Energy Rev. 2008, 12, 1129-1147.

79. Gross, C. Community perspectives of wind energy in Australia: The application of a justice and community fairness framework to increase social acceptance. Energy Policy 2007, 35, 2727-2736.

80. Walker, G.; Devine-Wright, P.; Hunter, S.; High, H.; Evans, B. Trust and community: Exploring the meanings, contexts and dynamics of community renewable energy. Energy Policy 2010, 38, 2655-2663.

81. Christensen, P.; Lund, H. Conflicting views of sustainability: The case of wind power and nature conservation in Denmark. Eur. Environ. 1998, 8, 1-6.

82. Devine-Wright, P. Rethinking NIMBYism: The role of place attachment and place identity in explaining place-protective action. J. Community Appl. Soc. Psychol. 2009, 19, 426-441.

83. Warren, C.R.; McFadyen, M. Does community ownership affect public attitudes to wind energy? A case study from south-west Scotland. Land Use Policy 2010, 27, 204-213.

84. Van der Horst, D.; Toke, D. Exploring the landscape of wind farm developments; local area characteristics and planning process outcomes in rural England. Land Use Policy 2010, 27, 214-221.

85. Cass, N.; Walker, G. Emotion and rationality: The characterisation and evaluation of opposition to renewable energy projects. Emot. Space Soc. 2009, 2, 62-69.

86. McLaren Loring, J. Wind energy planning in England, Wales and Denmark: Factors influencing project success. Energy Policy 2007, 35, 2648-2660.

87. Walker, G. The role for "community" in carbon governance. Wiley Interdiscip. Rev. 2011, 2 , 777-782.

88. Cowell, R.; Bristow, G.; Munday, M. Acceptance, acceptability and environmental justice: The role of community benefits in wind energy development. J. Environ. Plan. Manag. 2011, 54, 539-557.

89. Toke, D. Wind power in UK and Denmark: Can rational choice help explain different outcomes? Environ. Polit. 2002, 11, 83-100.

90. Toke, D.; Lauber, V. Anglo-Saxon and German approaches to neoliberalism and environmental policy: The case of financing renewable energy. Geoforum 2007, 38, 677-687. 
91. Stenzel, T.; Frenzel, A. Regulating technological change-The strategic reactions of utility companies towards subsidy policies in the German, Spanish and UK electricity markets. Energy Policy 2008, 36, 2645-2657.

92. Mendonca, M.; Lacey, S.; Hvelplund, F. Stability, participation and transparency in renewable energy policy: Lessons from Denmark and the United States. Policy Soc. 2009, 27, 379-398.

93. Sovacool, B.K. The policy challenges of tradable credits: A critical review of eight markets. Energy Policy 2011, 39, 575-585.

94. Woodman, B.; Mitchell, C. Learning from experience? The development of the renewables obligation in England and Wales 2002-2010. Energy Policy 2011, 39, 3914-3921.

95. O'Hare, M. Not on my block you don't: Facility siting and the strategic importance of compensation. Public Policy 1977, 25, 407-458.

96. Frey, B.S.; Oberholzer-Gee, F. The cost of price incentives: An empirical analysis of motivation crowding- out. Am. Econ. Rev. 1997, 87, 746-755.

97. Claro, E. Exchange relationships and the environment: The acceptability of compensation in the siting of waste disposal facilities. Environ. Values 2007, 16, 187-208.

98. Kunreuther, H.; Kleindorfer, P.; Knez, P.J.; Yaksick, R. A compensation mechanism for siting noxious facilities: Theory and experimental design. J. Environ. Econ. Manag. 1987, 14, 371-383.

99. O'Sullivan, A. Voluntary auctions for noxious facilities: Incentives to participate and the efficiency of siting decisions. J. Environ. Econ. Manag. 1993, 25, S12-S26.

100. Alain, J.-M.; Marchetti, N.; Tidball, M.M. Low-bid Auction Versus High-bid Auction For Siting Noxious Facilities in a Two-City Region: An Exact Approach; CIRANO Working Paper; Cenre Interuniversitaire de Recherche en Analyse des Organisations: Montreal, Canada, 2004.

101. Besfamille, M.; Lozachmeur, J.-M. NIMBY and mechanism design under different constitutional constraints. Int. Tax Public Financ. 2009, 17, 114-132.

102. Yengin, D. Identical Preferences Lower Bound for Allocation of Heterogeneous Tasks and NIMBY Problems; Research Paper; University of Adelaide, School of Economics: Adelaide, SA, Australia, 2011.

103. Quah, E. Cost-benefit analysis and the problem of locating environmentally noxious facilities. J. Int. Dev. 1994, 6, 79-92.

104. Lüthi, S.; Prässler, T. Analyzing policy support instruments and regulatory risk factors for wind energy deployment—A developers' perspective. Energy Policy 2011, 39, 4876-4892.

105. European Commission. SEC(2009) 503 Final: Working Document: The Renewable Energy Progress Report Accompanying Document to the Communication from the Commission to the Council and the European Parliament; European Commission: Brussels, Belgium, 2009.

106. Ecorys; Eclareon; EREC; Golder Associates. Assessment of Non-Cost Barriers to Renewable Energy Growth in EU Member States; Ecorys: Rotterdam, The Netherlands, 2010.

107. Nadaï, A. "Planning", "siting" and the local acceptance of wind power: Some lessons from the French case. Energy Policy 2007, 35, 2715-2726.

108. Ragwitz, M.; Held, A.; Resch, G.; Faber, T.; Haas, R.; Huber, C.; Morthorst, P.; Jensen, S.G.; Coenraads, R.; Voogt, M.; et al. OPTRES: Assessment and Optimisation of Renewable Support Schemes in the European Electricity Market; Intelligent Energy for Europe; ISI, EEG, ECOFYS, Risoe, LEI, EnBW: Karlsruhe, Germany, 2007. 
109. Borggrefe, F.; Nüßler, A. Auswirkungen fluktuierender Windverstromung auf Strommärkte und Übertragungsnetze. UmweltWirtschaftsForum 2009, 17, 333-343.

110. ENTSO-E Ten-Year Network Development Plan 2010-2020; European Network of Transmission System Operators for Electricity (ENTSO-E): Brussels, Belgium, 2010.

111. De Decker, J.; Kreutzkamp, P. Offshore Electricity Grid Infrastructure in Europe-A TechnoEconomic Assessment; European Wind Energy Association (EWEA): Brussels, Belgium, 2011.

112. BDEW. Abschätzung des Ausbaubedarfs in deutschen Verteilungsnetzen aufgrund von Photovoltaik- und Windeinspeisungen bis 2020; Bundesverband der Energie und Wasserwirtschaft (BDEW): Berlin, Germany, 2011.

113. Baldick, R.; Kahn, E. Network costs and the regulation of wholesale competition in electric power. J. Regul. Econ. 1993, 5, 367-384.

114. Stoft, S. Power System Economics: Designing Markets for Electricity; IEEE Press \& Wiley Interscience: Hoboken, NJ, USA, 2002; Volume 2.

115. Ackermann, T. Distributed Resources in a Re-Regulated Market Environment. Ph.D. Dissertation, KTH Royal Institute of Technology, Stockholm, Sweden, 2004.

116. Li, F.; Tolley, D.; Padhy, N.P.; Wang, J. Framework for assessing the economic efficiencies of long-run network pricing models. IEEE Trans. Power Syst. 2009, 24, 1641-1648.

117. Brandstätt, C.; Brunekreeft, G.; Friedrichsen, N. Smart Pricing to Reduce Network Investment in Smart Distribution Grids-Experience in Germany. In Smart Grid: Integrating Renewable, Distributed and Efficient Energy; Sioshansi, F.P., Ed.; Elsevier: Amsterdam, The Netherlands, 2011.

118. Lopes, J.A.P.; Hatziargyriou, N.; Mutale, J.; Djapic, P.; Jenkins, N. Integrating distributed generation into electric power systems: A review of drivers, challenges and opportunities. Electr. Power Syst. Res. 2007, 77, 1189-1203.

119. Brunekreeft, G.; Neuhoff, K.; Newbery, D. Electricity transmission: An overview of the current debate. Util. Policy 2005, 13, 73-93.

120. Teckenburg, E.; Rathmann, M.; Winkel, T.; Ragwitz, M.; Steinhilber, S.; Resch, G.; Panzer, C.; Busch, S.; Konstantinaviciute, I. Renewable Energy Country Profiles; ECOFYS, Fraunhofer ISI, Energy Economics Group, LEI: Karlsruhe, Germany, 2011.

121. Brandstätt, C.; Brunekreeft, G.; Jahnke, K. How to deal with negative power price spikes? Flexible voluntary curtailment agreements for large-scale integration of wind. Energy Policy 2011, 39, 3732-3740.

122. Brandstätt, C.; Brunekreeft, G.; Friedrichsen, N. Locational signals to reduce network investments in smart distribution grids: What works and what not? Util. Policy doi:10.1016/j.jup.2011.07.001, in press.

123. National Grid. Connection and Use of System Code (CUSC) 2011, Section 14: Charging Methodologies; National Grid: Northampton, UK, 2011.

124. ENA. EHV Distribution Charging Methodology (EDCM); Energy Networks Association (ENA): London, UK, 2011. 
125. Bundesregierung. Verordnung über die Entgelte für den Zugang zu Elektrizitätsversorgungsnetzen (Stromnetzentgeltverordnung —StromNEV); BGB1. I S. 2225; Bundesregierung: Berlin, Germany, 25 July 2005. Available online: http://www.gesetze-im-internet.de/bundesrecht/stromnev/gesamt.pdf (accessed on 15 February 2012).

126. Nicolosi, M. Wind power integration and power system flexibility-An empirical analysis of extreme events in Germany under the new negative price regime. Energy Policy 2010, 38, 7257-7268.

127. European Parliament. Council Directive 2009/28/EC of the European Parliament and of the Council of 23 April 2009 on the Promotion of the Use of Energy from Renewable Sources and Amending and Subsequently Repealing Directives 2001/77/EC and 2003/30/EC; European Parliament: Brussels, Belgium, 2009.

128. White \& Case. EEG-Novelle 2012 im Überblick; White \& Case: Köln, Germany, 2011.

129. Sensfuß, F.; Ragwitz, M.; Kratzat, M.; Langniß, O.; Obersteiner, C.; Müller, T.; Merten, F.; Fischedick, M. Fortentwicklungdes Erneuerbaren Energien Gesetzes (EEG) zur Marktdurchdringung Erneuerbarer Energienim Deutschen und Europäischen Strommarkt; Fraunhofer ISI: Karlsruhe, Germany, 2007.

130. Klein, A.; Pfluger, B.; Held, A.; Resch, G.; Faber, T. Evaluation of Different feed-in Tariff Design Options-Best Practice Paper for the International Feed-In Cooperation; Energy Economics Group/Fraunhofer ISI: Karlsruhe, Germany, 2008.

131. DECC. Planning our Electric Future: A White Paper for Secure, Affordable and Low Carbon electricity; Department of Energy and Climate Change (DECC): London, UK, 2011.

132. DECC. Planning Our Electric Future: Technical Update; Department of Energy and Climate Change (DECC): London, UK, 2011.

133. Couture, T.; Gagnon, Y. An analysis of feed-in tariff remuneration models: Implications for renewable energy investment. Energy Policy 2010, 38, 955-965.

134. Newbery, D. Contracting for Wind Generation; Cambridge Working Paper in Economics; University of Cambridge: Cambridge, UK, 2011.

135. Doherty, R.; O’Malley, M. The efficiency of Ireland's Renewable Energy Feed-In Tariff (REFIT) for wind generation. Energy Policy 2011, 39, 4911-4919.

136. European Commission, DG Competition. SEC (2006) 1724: Report on Energy Sector Inquiry; European Commission, DG Competition: Brussels, Belgium, 2007.

137. Brunekreeft, G. Anreizregulierung bei erhöhtem Investitionsbedarf in Stromverteilnetze. Energiewirtschaftliche Tagesfr. 2011, 61, 15-18.

138. Müller, C.; Growitsch, C.; Wissner, M. Regulierung, Effizienz und das Anreizdilemma bei Investitionen in intelligente Netze. Z. Energiewirtschaft 2011, 35, 159-171.

139. Bauknecht, D.; Koch, M. Netzinnovationen und Netzregulierung im Dilemma zwischen Kosteneffizienz und Investitionsbedarf. Energiewirtschaftliche Tagesfr. 2010, 12, 8-11.

140. OFGEM. RIIO - A New Way to Regulate Energy Networks_Final Decision; Factsheet; Ofgem: London, UK, 2010.

141. Dyer, C.H.; Hammond, G.P.; Jones, C.I.; McKenna, R.C. Enabling technologies for industrial energy demand management. Energy Policy 2008, 36, 4434-4443.

142. Faruqui, A.; Hledik, R.; Tsoukalis, J. The power of dynamic pricing. Electr. J. 2009, 22, 42-56. 
143. Faruqui, A.; Harris, D.; Hledik, R. Unlocking the $€ 53$ billion savings from smart meters in the EU: How increasing the adoption of dynamic tariffs could make or break the EU's smart grid investment. Energy Policy 2010, 38, 6222-6231.

144. Andersson, S.-L.; Elofsson, A.K.; Galus, M.D.; Göransson, L.; Karlsson, S.; Johnsson, F.; Andersson, G. Plug-in hybrid electric vehicles as regulating power providers: Case studies of Sweden and Germany. Energy Policy 2010, 38, 2751-2762.

145. Borggrefe, F.; Neuhoff, K. Balancing and Intraday Market Design: Options for Wind Integration; DIW Discussion Paper; Deutsches Institut für Wirtschaftsforschung (DIW): Berlin, Germany, 2011.

146. Zhang, T.; Nuttall, W.J. An Agent Based Simulation of Smart Metering Technology Adoption; Cambridge Working Papers in Economics; Faculty of Economics, University of Cambridge: Cambridge, UK, 2007.

147. Jaffe, A.; Stavins, R.N. The energy paradox and the diffusion of conservation technology. Resour. Energy Econ. 1994, 16, 91-122.

148. European Parliament Council Directive 2010/31/EC of the European Parliament and of the Council of 19 May 2010 on the Energy Performance of Buildings (Recast); European Parliament: Brussels, Belgium, 2010.

149. Wissner, M. Smart Metering; WIK Diskussionsbeitrag; Wissenschaftliches Institut für Infrastruktur und Kommunikationsdienste (WIK): Bad Honnef, Germany, 2009.

150. DENA. Dena Grid Study II-Integration of Renewable Energy Sources in the German Power Supply System from 2015-2020 with an Outlook to 2025; Deutsche Energie-Agentur (DENA): Berlin, Germany, 2010.

151. Von Hirschhausen, C.; Wand, R.; Beestermöller, C. Bewertung der dena-Netzstudie II und des europäischen Infrastrukturprogramms; Technical University Berlin: Berlin, Germany, 2010.

152. Klessmann, C.; Lamers, P.; Ragwitz, M.; Resch, G. Design options for cooperation mechanisms under the new European renewable energy directive. Energy Policy 2010, 38, 4679-4691.

153. Muñoz, M.; Oschmann, V.; David Tàbara, J. Harmonization of renewable electricity feed-in laws in the European Union. Energy Policy 2007, 35, 3104-3114.

154. Söderholm, P. Harmonization of renewable electricity feed-in laws: A comment. Energy Policy 2008, 36, 946-953.

155. SRU. Wege zur 100\% Erneuerbaren Stromerzeugung; Sachverständigenrat für Umweltfragen (SRU): Berlin, Germany, 2011.

156. Markard, J.; Truffer, B. Technological innovation systems and the multi-level perspective: Towards an integrated framework. Res. Policy 2008, 37, 596-615.

157. Geels, F.W.; Schot, J. Typology of sociotechnical transition pathways. Res. Policy 2007, 36, 399-417.

158. Verbong, G.; Geels, F. The ongoing energy transition: Lessons from a socio-technical, multilevel analysis of the Dutch electricity system (1960-2004). Energy Policy 2007, 35, 1025-1037.

159. Deakins, D.; Freel, M. Entrepreneurial learning and the growth process in SMEs. Learn. Organ. 1998, 5, 144-155.

160. Hall, P.A. Policy paradigms, social learning, and the state: The case of economic policymaking in Britain. Comp. Polit. 1993, 25, 275-296. 
161. Geels, F.; Deuten, J.J. Local and global dynamics in technological development: A socio-cognitive perspective on knowledge flows and lessons from reinforced concrete. Sci. Public Policy 2006, $33,265-275$.

162. Szarka, J. Wind power, policy learning and paradigm change. Energy Policy 2006, 34, 3041-3048.

163. Verbong, G.; Geels, F.W.; Raven, R. Multi-niche analysis of dynamics and policies in Dutch renewable energy innovation journeys (1970-2006): Hype-cycles, closed networks and technology-focused learning. Technol. Anal. Strateg. Manag. 2008, 20, 555-573.

164. Truffer, B.; Voß, J.-P.; Konrad, K. Mapping expectations for system transformations: Lessons from Sustainability Foresight in German utility sectors. Technol. Forecast. Soc. Change 2008, $75,1360-1372$.

165. Azariadis, C. Self-fulfilling prophecies. J. Econ. Theory 1981, 25, 380-396.

166. Henshel, R.L. Do self-fulfilling prophecies improve or degrade predictive accuracy? How sociology and economics can disagree and both be right. J. Socio Econ. 1993, 22, 85-104.

167. Hermens, A. Knowledge exchange in strategic alliances: Learning in tension. Creat. Innov. Manag. 2001, 10, 189-200.

168. Raven, R.P.J.M.; Heiskanen, E.; Lovio, R.; Hodson, M.; Brohmann, B. The contribution of local experiments and negotiation processes to field-level learning in emerging (Niche) technologies. Bull. Sci. Technol. Soc. 2008, 28, 464-477.

169. Jacobsson, S.; Lauber, V. The politics and policy of energy system transformation-Explaining the German diffusion of renewable energy technology. Energy Policy 2006, 34, 256-276.

170. Lewis, J.I.; Wiser, R.H. Fostering a renewable energy technology industry: An international comparison of wind industry policy support mechanisms. Energy Policy 2007, 35, 1844-1857.

(C) 2012 by the authors; licensee MDPI, Basel, Switzerland. This article is an open access article distributed under the terms and conditions of the Creative Commons Attribution license (http://creativecommons.org/licenses/by/3.0/). 